\title{
Characteristics of Sudan III-Poly(N Vinylcarbazole) Composite Film for Optical Sensor Application
}

\author{
Heindrich Taunaumang ${ }^{1}$, Raindy Xaverius Dumais ${ }^{1}$, and Jinno Pondaag ${ }^{1}$
}

\begin{abstract}
Photo-responsive molecule Sudan III has been developed in form of thin film to pursue their excellent properties especially for optical sensor device application. However, thin film of Sudan III possesses a weak mechanical property. And therefore in order to enhance this functional property of the Sudan III molecule was embedded within polymer matrix to form composite material. In this research, the thin films composite of Sudan III-Poly(N-Vinylcarbazole) or Sudan III/PVK were fabricated by using casting and spin coating methods. The structure of Sudan III-Poly(NVinylcarbazole) composite material were characterized by using FTIR, XRD measurement and for the optical property (absorbance) by UV-VIS measurement. In this paper the experiment results are presented.
\end{abstract}

Keywords - composite material, spin coating, Sudan III, optical property.

Abstrak-Molekul fotoresponsif Sudan III telah dikembangkan dalam bentuk film untuk mendapatkan sifat material yang unggul khususnya untuk aplikasi devais sensor optik. Namun, film Sudan III memiliki sifat mekanik yang lemah. Karena itu untuk pemanfaatan sifat fungsional molekul Sudan III maka molekul ini, ditempatkan sedemikian di dalam matriks polimer agar membentuk material komposit. Dalam riset ini film komposit Sudan III-Poly (N-Vinylcarbazole) atau Sudan III/PVK telah difabrikasi dengan menggunakan metode kasting dan pelapisan-putar. Stuktur bahan komposit Sudan III-Poly(N-Vinylcarbazole) dikarakterisasi dengan menggunakan melalui pengukuran FTIR, XRD dan untuk sifat optik (absorbansi) dilakukan dengan pengukuran UV-VIS. Dalam tulisan ini membahas tentang hasil-hasil eksperimen.

Kata Kunci-material komposit, pelapisan-putar, Sudan III, sifat optik.

\section{INTRODUCTION}

A log-logistic Research on azobenzene based molecules such as DR1, DR19 and Sudan III have been studied $[1,2,3,4,5]$. These molecules consists of $\mathrm{OH}$ and $\mathrm{N}=\mathrm{N}$ groups which are responsive to optical field and its environment (others molecules) through molecular interaction such as hydrogen bonding or Van der Walls interaction. The optical property (absorbance) is strongly influenced by the formation (cis-trans) of azobenzene molecules [6]. In this work, composite film of Sudan III/PVK was fabricated for sensor devices application. The gas sensor technology is important for controlling pollution or hazard gas (gas corrosive) such as $\mathrm{H}_{2} \mathrm{~S}, \mathrm{CO}_{2}$ which related to clean environment protection. For sensor technology devices applications the sensitivity, selectivity and responsive time are required and these characteristics are strongly determined by physical and chemical properties of the materials used $[7,8,9,10]$. Material responsive used in this research is Sudan III. However, thin film of this molecule possesses a weak mechanical property and therefore for sensor technology applications this molecule should be embedded within polymer matrix such as poly (N-vinylcarbazole) or PVK, PMMA.

In this work, the thin film composite of Sudan III/PVK have been fabricated by using casting and spin coating solution methods and this film possesses smooth

${ }^{1}$ Heindrich Taunaumang, Raindy Xaverius Dumais, and Jinno Pondaag are with Departement of Physics, Faculty of Mathematics and Natural Sciences, Universitas Negeri Manado, Tondano, 95618, Indonesia. Email: hein.taunaumang@yahoo.com; raindydumais@yahoo.com; pondaag.jinno@gmail.com. surfaces, homogenous thickness, and good optical stability.

This paper is intended to study the structure and the optical characteristic of Sudan III/PVK composite film which were obtained from the FTIR, XRD and UV-VIS measurement.

\section{METHOD}

\section{A. Material Used}

\section{1) Sudan III}

Photo-responsive material used in this research is Sudan III. Purchased from Sigma. The structure of this molecule is shown in figure 1.

2) Poly (N-vinylcarbazole)

Poly(N-vinylcarbazole) or PVK is known as a polymer photoconductive. This molecule has Glass transition $200 \mathrm{oC}$ and refractive index no, $20=1.696$. The polymer structure is shown in Figure 2. This polymer was purchased from sigma in form of pellet.

\section{B. Samples Preparation}

The solution of Sudan III and PVK samples were prepared by dissolving Sudan III and PVK powder respectively into cloroform as a solvent. The homogeneous solution of Sudan III and PVK were obtained by stiring the solution for about six hour by using a magnetic stirer.

The solutions of Sudan III//PVK were prepared with different composition (\% weight ratio) as the following:

a. Sudan III/PVK (1:3)

b. Sudan III/PVK (1:4)

The film of PVK and film composite of Sudan III/PVK with 1:3 and 1:4 were prepared by using spin coating method. 


\section{Samples Characterization \\ 3) FTIR Measurement}

In this research the molecular structure are characterized by using FT-IR 801 Single Beam Spectrophotometer. The measurement was carried out in the "frequencies" (wave number) range of 4600-400 cm1. From the FTIR spectra can be identified the molecular structure of the composite material. The absorption spectra indicate the interaction between electromagnetic radiation (IR radiation) and electrical dipole moment.

The absorption peaks (A) in the FTIR spectra are corresponding to an electrical dipole moment transition of the molecule $(\mu)$ and the electric field radiation vector (E) according to the following equation (1) [13].

$\mathrm{A} \propto\left(\frac{\partial \bar{\mu}_{\mathrm{n}}}{\partial \mathrm{r}} \cdot \overline{\mathrm{E}}\right)^{2}=\left(\frac{\partial \mu_{\mathrm{n}}}{\partial \mathrm{r}} \mathrm{E}\right)^{2} \cos ^{2} \theta$

Where $\frac{\partial \bar{\mu}_{n}}{\partial \mathrm{r}} \quad$ is a modus of dipole moment transition and $\overline{\mathrm{E}}$ is the electric field of IR radiation, and $\theta$ is the angle between the dipole moment transition and the electric field.

\section{2) XRD Measurement}

X-Ray Diffraction (XRD) been used for investigation of a crystalline structure such as crystalline order, crystalline orientation and also for estimation of crystalline size material.

The XRD measurement has been carried out by using a diffractometer that based on the reflection method of $\mathrm{X}$ ray radiation. The XRD spectra were performed as diffraction peak intensity corresponding to the diffraction angle. From the spectra of XRD measurement can be determined the planes distance of the crystal $\left(\mathrm{d}_{\mathrm{hkl}}\right)$ according to the Bragg equation (2) [14].

$\mathrm{d}_{\mathrm{hkl}}=\frac{\lambda}{2 \sin \theta}$

Where $\mathrm{h}, \mathrm{k}$ and $\mathrm{l}$ indicate the lattice plane parameter, $\lambda$ indicates $\mathrm{x}$-ray wave length, and $2 \theta$ is diffraction angle. For organic polymer usually using $\mathrm{Cu}-\mathrm{K} \alpha$. The peak intensity and width of the XRD spectra can be related to the crystalline order or crystal size and also molecules orientation in the film. The width of the XRD spectra $\left(\mathrm{B}_{\mathrm{hkl}}\right)$ corresponding to the crystal size which is stated by the Scherer formula in equation (3) [15]:

$\mathrm{B}_{\mathrm{hkl}}=\mathrm{k} \lambda / \mathrm{D}_{\mathrm{hkl}} \cos \theta$

Where $\lambda$ is the wavelength of XRD radiation. $D_{h k 1}$ is the crystalline size, and $\theta$ is the Bragg angle, and $\mathrm{k}$ is a constant $(k=0,89)$. Sample which has a small crystalline size indicate a wide diffraction peak.

In this experiment the XRD measurement has been carried out in the range of diffraction angle: $10-80^{\circ}$, by using Philips Diffractometer. In this measurement diffraction XRD pattern was record and scanned in $2 \theta$ at $30 \mathrm{kV}, 30 \mathrm{~mA}$ with radiation source $\mathrm{Cu} \mathrm{K \alpha}$ ( $\alpha=1,5406$ Angstrom).

3) UV-VIS measurement

The optical characteristics of Sudan III molecules and PVK in form of solution and film were obtained from UV-VIS measurement. This measurement was carried out using an instrument of Beckmen DU-7000 Single Beam Spectrophotometer. This measurement obtained UV-VIS spectra in range of 250-800 $\mathrm{nm}$. The background of the sample was first measured. The solvent used for Sudan III and PVK solution samples were chloroform.

The electronic transition energy is depends on frequency $(v)$, wave number $(\mathrm{k})$ according to equation (4). [16]

$$
\Delta \mathrm{E}=\mathrm{h} v=\mathrm{hc} / \lambda
$$

Experimentally, the absorption intensity can be stated according to the Lambert-Beer law as the following: [16] $A(v)=\log _{10} \frac{I_{o}}{I}=\varepsilon(v) c L$

With $I_{o}$ is incident light intensity, $I$ is light intensity after passing the sample. $\varepsilon(v)$ is molar absorption (extension coefficient) at certain frequency $v ; c$ is concentration (gram moles/liter), and L is path length of light $(\mathrm{cm})$. Molar absorption coefficient $\varepsilon$ can be related to absorption coefficient $\alpha$ according to the formula: $\varepsilon=\alpha$ $\ln 10=\alpha / 2.303$.

\section{RESULT AND DISCUSSION}

\section{A. Ftir Measurement Results}

Figure 3 shows the FTIR spectra of Sudan III powder in $\mathrm{KBr}$ matrix. Figure 4 shows the FTIR spectra of PVK powder in $\mathrm{KBr}$ matrix. Figure 5 shows the FTIR spectra of PVK film. Figure 6 and 7 show the FTIR spectra of composite Sudan III/PVK powder in $\mathrm{KBr}$ matrix.

The N=N stretching in Sudan III/PVK composite powder material is relatively more stronger then for Sudan III which indicates that the Sudan III in polymer matrix is more freely it is mean that the separation between Sudan III molecule within polymer matrix is bit larger. The composite material structure as a combination of both material namely Sudan III and PVK.

\section{B. XRD Measurement Results}

Figure 8 and 9 show the XRD measurements results of Sudan III/PVK composite film. Figure 8 and 9 are the XRD pattern for Sudan III/PVK composite film. These figure show a wide XRD pattern which indicates that the sample has a small crystalline size or low crystalline order. However for Sudan III (figure 11) powder show sharp XRD pattern which indicates that Sudan III possesses a big crystalline size or high crystalline order. Figure 10 is the XRD pattern of PVK film. This XRD pattern is similarly with figure 8 and 9 .

Figure 11 show the XRD pattern of Sudan III pristine powder. Figure 12 shows the XRD pattern of PVK powder.

The XRD pattern of PVK powder indicates that the crystalline size is small.

\section{UV-VIS Measurement Results}

Figure 13 (A) shows UV-VIS Spectra of of solution of PVK in chloroform solvent and the figure 13 (B) shows UV-VIS Spectra of solution of Sudan III in chloroform solvent. The UV-VIS of Sudan III shows a maximum absorption $\left(\lambda_{\max }\right)$ at $517 \mathrm{~nm}$, and $345 \mathrm{~nm}$, and $299 \mathrm{~nm}$ corresponding to electronic energy transition of $2.4 \mathrm{eV}$, and $3,6 \mathrm{eV}$ and $4.2 \mathrm{eV}$ respectively. This spectra exhibits a broad absorption band at $517 \mathrm{~nm}$, with high intensity which indicates of strong oscillator of Sudan III molecule. This absorption band corresponding to $\pi-\pi^{*}$ electronic transition through azobenzene. 
Figure 13 (A) shows UV-VIS spectra for sample of PVK solution (chloroform) that do not exhibit absorption band in visible region. In other word, the visible region is transparent. However this spectra shows two maximum absorptions in UV region i.e., at $299 \mathrm{~nm}$ and $345 \mathrm{~nm}$ which corresponding to electronic energy transition of $4.2 \mathrm{eV}$ and 3,6 eV. This spectra exhibits a narrow absorption band with low intensity which indicates of weak oscillator of PVK. This absorption band corresponding to $\pi-\pi^{*}$ electronic transition in benzene.

The UV-VIS spectra (figure 15) shows an absorption peaks in visible region i.e., at $\lambda_{1}=517 \mathrm{~nm}$ and two maximum absorption in UU-region i.e., at $\lambda_{2}=345 \mathrm{~nm}$ and $\lambda_{3}=299 \mathrm{~nm}$ which corresponding to electronic energy transition of $\mathrm{E}_{1}=2.4 \mathrm{eV}$ and $\mathrm{E}_{2}=3,6 \mathrm{eV}$, and $\mathrm{E}_{3}$ $=4.2 \mathrm{eV}$ respectively. The figure do not shows a significant shifting in absorption peak to the longer wavelength (red-shift) or shifting to the shorter wavelength (blue-shift). The film of composite of Sudan III/PVK with composition 1:4 shows lower intensity and narrow absorption band in the visible region compared to the Sudan III/PVK with composition 1:3. The differences of absorption band form due to electronics transition contribution of Sudan III molecules in the composite. The UV-VIS spectra film Sudan III/PVK clearly shows absorption peak in the visible region and this potentially to be developed as optically sensor. The UV-VIS spectra film of Sudan III/PVK composites shows that the optical properties of the composites as combination of its optical properties components i.e., Sudan III and PVK.

\section{CONCLUSION}

FTIR spectra indicates that the composite material structure as a combination structure of Sudan III and PVK material. The $\mathrm{N}=\mathrm{N}$ stretching in Sudan III/PVK composite powder material is relatively more stronger then for Sudan III which indicates that the Sudan III in polymer matrix is more freely it is mean that the separation between Sudan III molecule within polymer matrix is bit larger.

The Sudan III/PVK composite film show a wide XRD pattern which indicates that the sample has a small crystalline size or low crystalline order. However for Sudan III powder show sharp XRD pattern which indicates that Sudan III possesses a big crystalline size or high crystalline order.

The optical characteristic especially in absorbance intensity for UV region (345 nm) of Sudan III/PVK composite in form of solution is significantly different compared to the film composite. However, in visible region is relatively stable.

This UV-VIS measurement indicates that the film of Sudan III/PVK can be potentially to be developed for optical sensor application.

\section{ACKNOWLEDGMENTS}

Thank for DP2M DIKTI (Directorate High Education of Indonesia) for funding this research By Grant of Hibah Bersaing with letter of agreement No:
31/SP2H/PL/Dit.Litabmas/IV/2011, April 14, 2011 and No.2772/UN41/023.04.08/2012, September 20, 2012.

\section{REFERENCES}

[1] H. Taunaumang and D. Taawoeda, "Efek Permukaan dan Suhu Substrat Pada Orientasi Molekul dan Momen Dipol Film Tipis Hasil Deposisi Vakum Dari Molekul Berbasis Azobenzene," Universitas Negri Manado, Manado, 2006.

[2] H. Taunaumang, D. Wenas and D. Taawoeda, "Pengembangan Material Fotorefraktif untuk Aplikasi Fotonik," Universitas Negeri Manado, Manado, 2008.

[3] D. Taawoeda and H. Taunaumang, "Pengembangan Material Fotorefraktif Untuk Aplikasi Fotonik," Universitas Negeri Manado, Manado, 2009.

[4] H. Taunamang and D. Taawoeda, "Pengembangan Film Tipis Komposit DR19/PVK untuk Aplikasi Sensor Optik," Universitas Negeri Manado, Manado, 2011.

[5] H. Taunaumang, "Fabrikasi dan Karakerisasi Film Tipis Komposit Sudan III/PVK.," Universitas Negeri Manado, Manado, 2012.

[6] M.-S. Ho, A. Natanshon and P. Rochon, "Azo Polymers for Reversible Optical Storage.9, Copolymers Containing Two Types of Azobenzene Side Groups, .," Macromolecules, vol. 29, no. 1, pp. 44-49, 1996.

[7] A. D. Kersey, "A Review of Recent Developments in Fiber Optic Sensor Technology," Optical Fiber Technology, vol. 2, no. 3, p. 291-317, 1996.

[8] K. R. Rogers and E. J. Poziome, "Fiber Optic Sensors For Environmental Monitoring," Chemosphere, vol. 33, no. 6, pp. 1151-1174, 1996.

[9] R. Ramamoorthy, P. K. Dutta and S. A. Akbar, "Oxygen Sensors: Materials, Methods, Designs and Applications," Journal of Materials Science, vol. 38, no. 21, p. 4271 - 4282, 2003.

[10] D. A. Parry, M. M. Sallah, L. S. Miller, I. R. Peterson and R. Hollyoak, "Investigation Into The Respons of an Optical Gas Sensor Based on Polymeric LB Films," Supramolecular Science, vol. 4, no. 3-4, pp. 427-435, 1997.

[11] O. Worsfold, C. Malins, M. G. Forkan, I. R. Peterson, B. D MacCraith and D. J. Walton, "Optical NO2 Sensing Based on Sol-Gel Entrapped Azobenzene Dyes," Sensors and Actuators B: Chemical, vol. 56, no. 1-2, p. 15-21, 1999.

[12] J. Luo, J. Qin, H. Kang and C. Ye, "A Postfunctionlization Strategy to Develop PVK-Based Nonlinear Optical Polymers with a High Density of Chromophore and Improved Processibility," Chem. Mater, vol. 13, pp. 927-931, 2011.

[13] N. B. Colthup, L. H. Daly and S. E. Wiberley, Introduction to Infrared and Raman Spectroscopy, London: Academic Press, 1975.

[14] E. Alkins, "X-Ray Structure Determination of Polymers," in Electronic structure of Polymers and Molecular Crystals, New York, Springer US, 1975, pp. 199-226.

[15] U. Gedde, Polymer Physics, London: Chapman \& Hall, 1995.

[16] R. W. Silverstein and G. C. Bassler, Spectrometer Identification of Organic Compounds, Second Edition, Michigan: John Willey \& Sons, Inc., 1967.

[17] X. Meng, A. Natanshon, C. Barret and P. Rochon, "Azopolymer for Reversible Optical Storage.10. Cooperative Motion of Polar Side Groups in Amorphous Polymers," Macromolecules, vol. 29 , no. 3, pp. 946-952, 1996. 


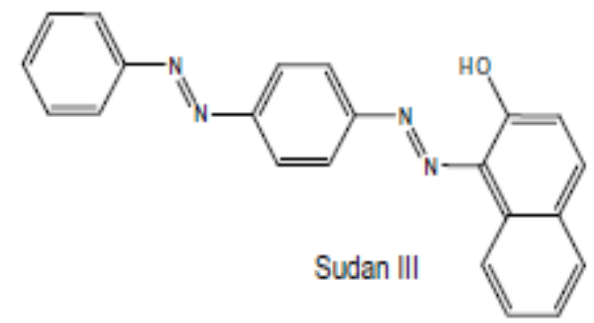

Figure 1. The molecular structure of Sudan III [11]

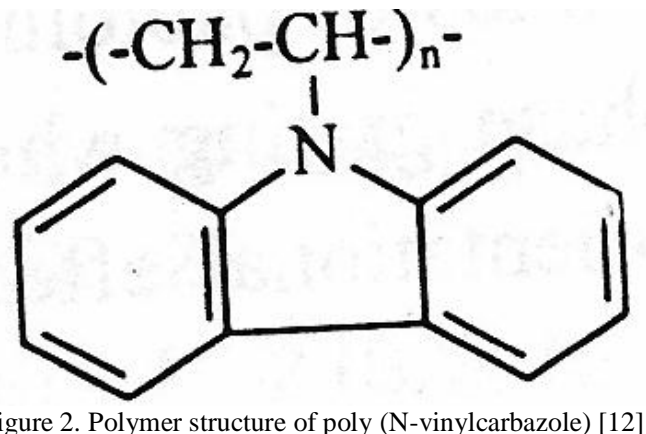

Figure 2. Polymer structure of poly (N-vinylcarbazole) [12]
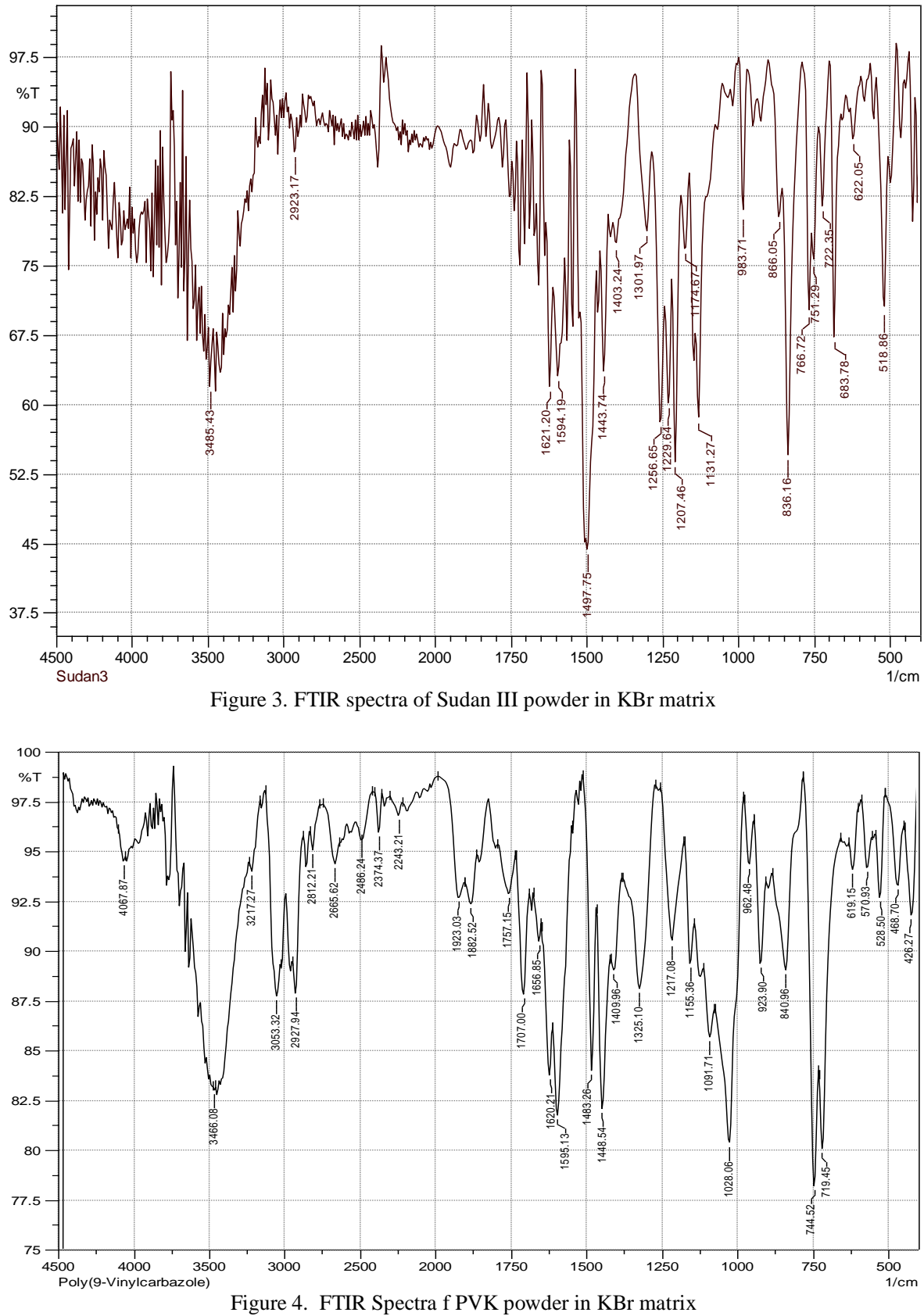

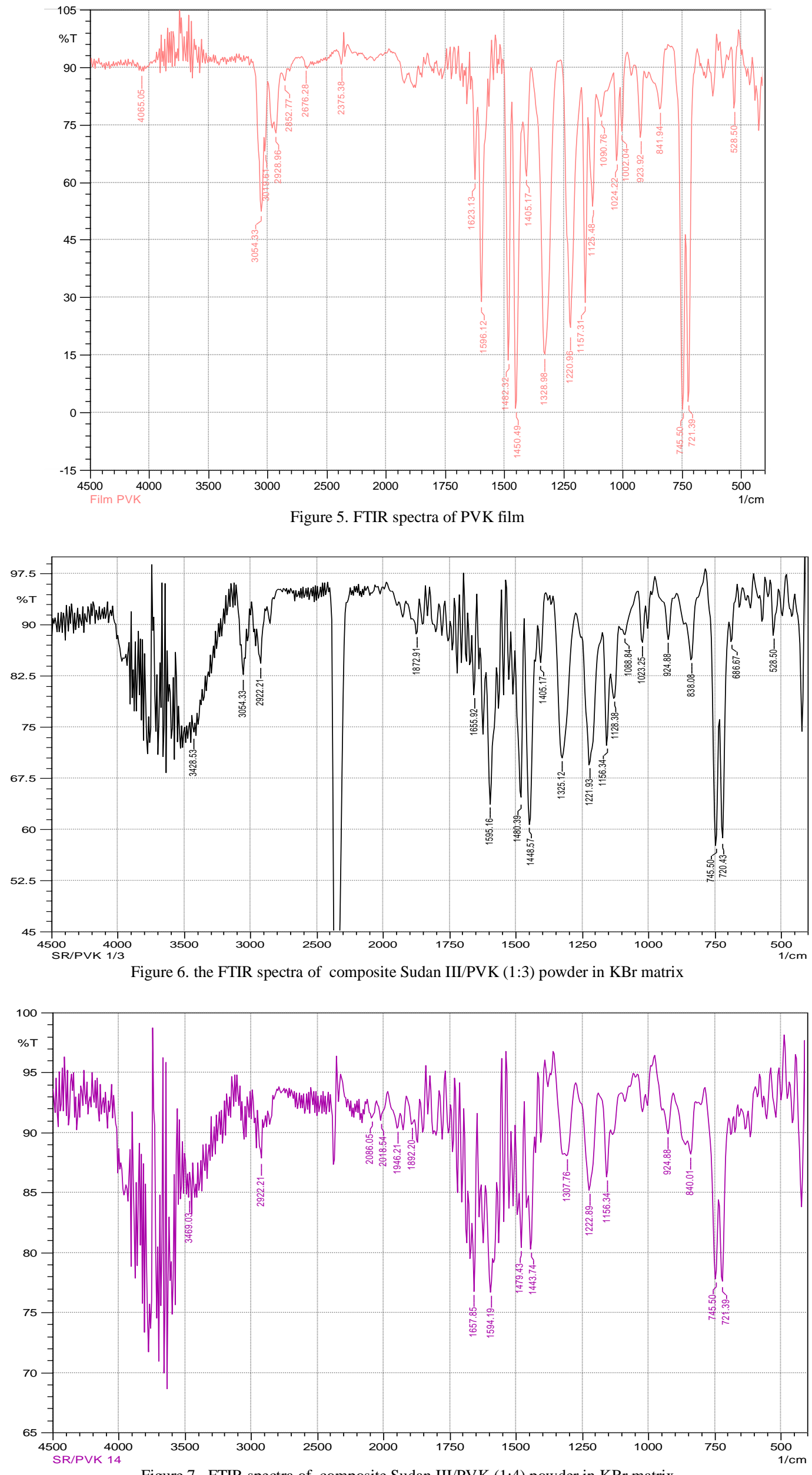

Figure 7. FTIR spectra of composite Sudan III/PVK (1:4) powder in KBr matrix 


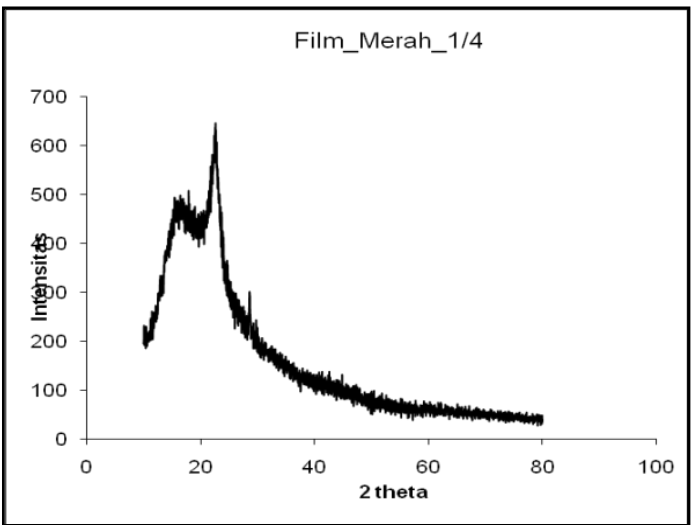

Figure 8 . The XRD pattern of composite Film of 1:4

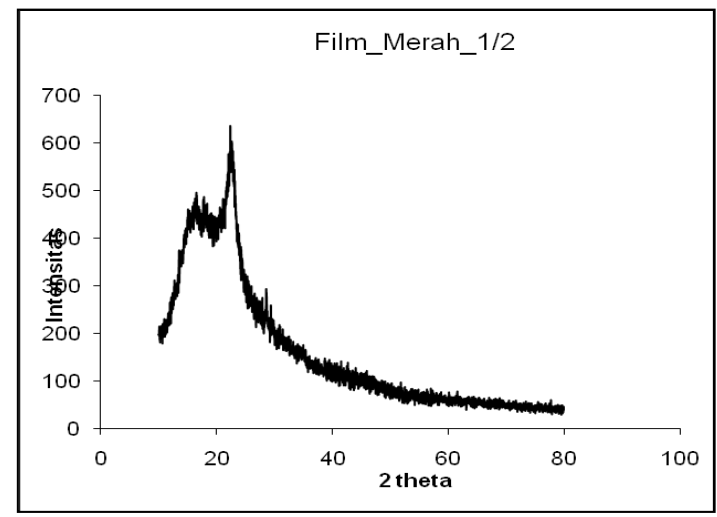

Figure 9. The XRD pattern of Sudan III/PVK composite Film of 1:3

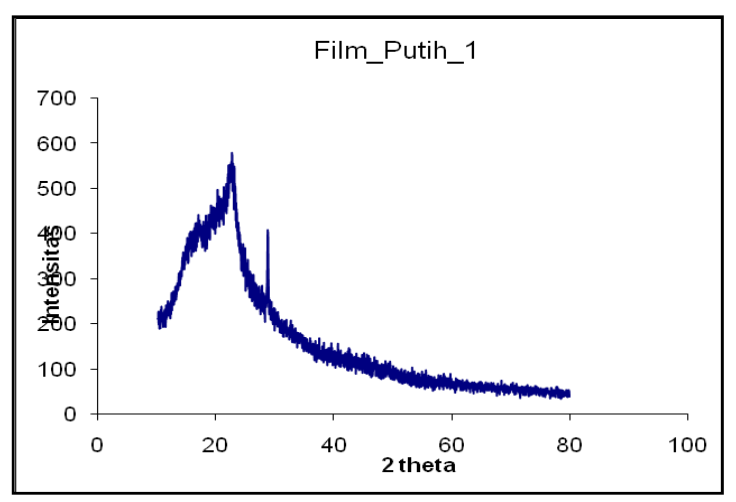

Figure 10. The XRD pattern of PVK film

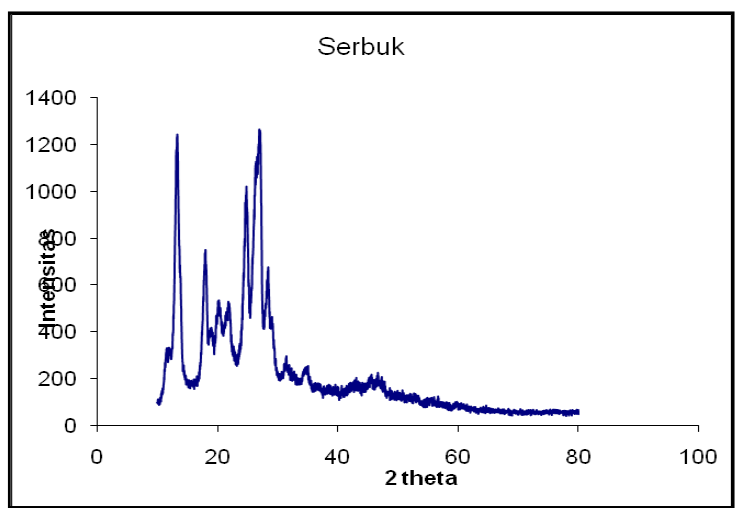

Figure 11. The XRD pattern of Sudan III pristine powder

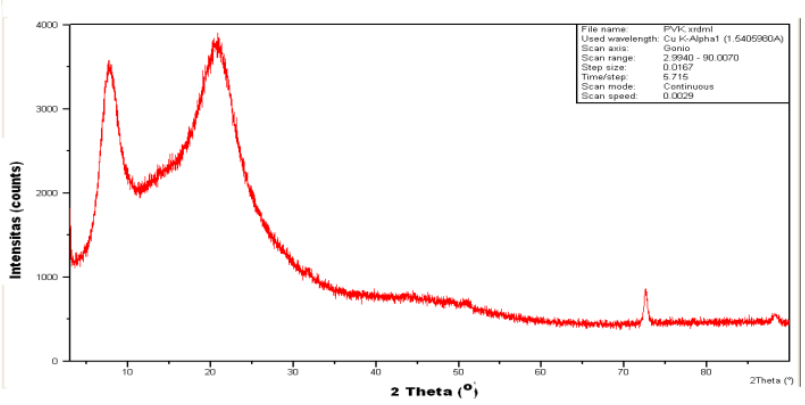

Figure 12. The XRD pattern of PVK powder

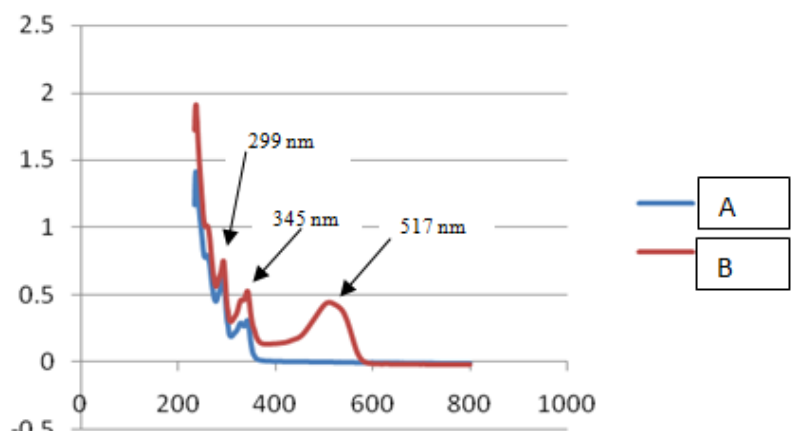

Figure 13. The Spectra of UV-VIS measurement of solution of (A). PVK in chloroform solvent. (B). Sudan III in chloroform solvent

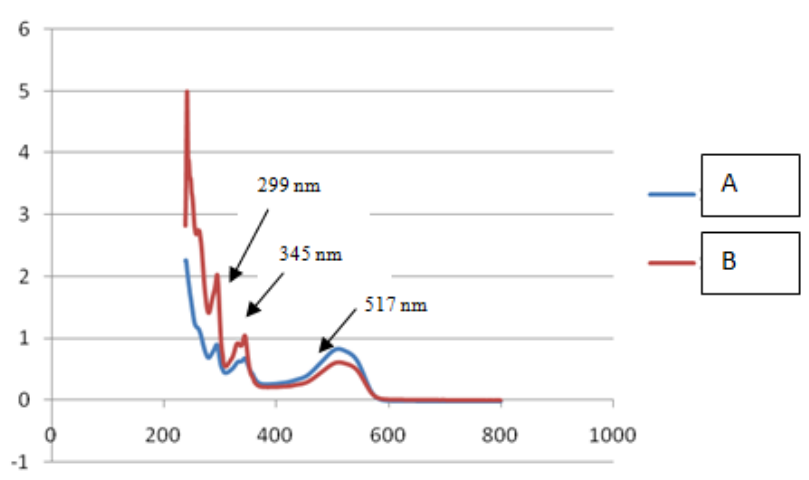

Figure 14. The Spectra of UV-VIS measurement of (A). Sudan III/PVK composite solution (chloroform solvent) with composition 1:3. (B). Sudan III/PVK composite solution (chloroform solvent ) with composition 1:4

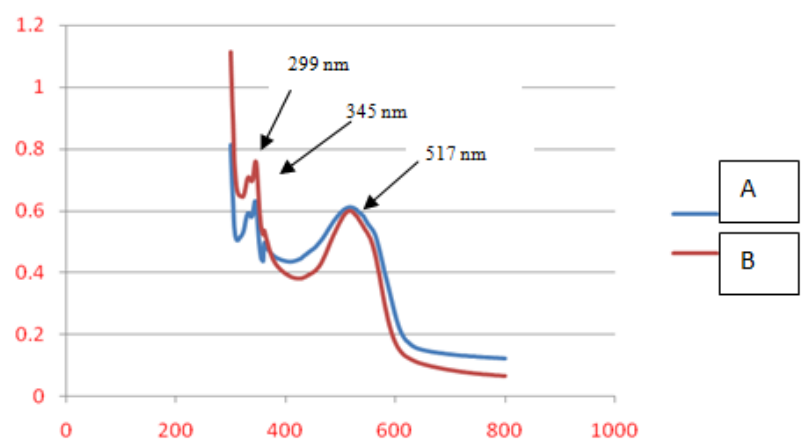

Figure 15. The Spectra of UV-VIS measurement of (A). Film of Sudan III/PVK composite with composition 1:3 produced by spin coating.(blue line) (B). Film of Sudan III/PVK composite with composition 1:4 produced by spin coating.(red line) 
TABLE 1.

\begin{tabular}{|c|c|c|}
\hline Position $\left(\mathrm{cm}^{-1}\right)$ & $\begin{array}{l}\text { Transmission } \\
\text { Intensity }\end{array}$ & Identification $[6,13,17]$ \\
\hline 3485 & S, wide & $\begin{array}{lll}\text { O-H stretching } & \text { of bounded } \\
\text { intermolecular }\end{array}$ \\
\hline 2924 & Vw & $\mathrm{C}-\mathrm{H}$ asymmetric stretching \\
\hline 2854 & Vw & C-H symmetric stretching \\
\hline 2962 & Vw & $\mathrm{C}-\mathrm{H}$ asymmetric stretcting \\
\hline 2873 & $\mathrm{Vw}$ & $\mathrm{C}-\mathrm{H}$ symmetric stretching \\
\hline 1621 & $\mathrm{~S}$ & $\mathrm{C}=\mathrm{C}$ (ring stretching) \\
\hline 1594 & $\mathrm{~S}$ & $\mathrm{C}=\mathrm{C}$ (ring stretching) \\
\hline 1497 & $S$ & $\mathrm{C}=\mathrm{C}$ (ring stretching $)$ \\
\hline 1443 & Vw & $\mathrm{N}=\mathrm{N}$ stretching \\
\hline 1301 & Vw & $\mathrm{O}-\mathrm{H}$ bending vibration \\
\hline 1256 & VS & C-O stretching vibration \\
\hline 1229 & $\mathrm{~S}$ & $\mathrm{OH}$ deformation \\
\hline 1207 & W & $\mathrm{C}-\mathrm{O}$ stretching vibration \\
\hline 1174 & Vw & $\mathrm{C}-\mathrm{N}$ (str.) in phenyl \\
\hline 1131 & $\mathrm{~W}$ & $\mathrm{C}-\mathrm{O}$ stretching of $\mathrm{C}-\mathrm{OH}$ group \\
\hline 863 & $\mathrm{~S}$ & C-H out-of-plane bending \\
\hline 836 & $\mathrm{~S}$ & C-H out-of-plane bending \\
\hline $683 \mathrm{~S}$ & $\mathrm{~S}$ & C-H out-of-plane bending \\
\hline 617 & W & $\mathrm{OH}$ wagging \\
\hline
\end{tabular}

Note : Vs: very strong, S: strong, W: weak, Vw: very weak

TABLE 2.

IDENTIFICATION OF THE FTIR ABSORPTION PEAKS OF PVK POLYMER IN KBR MATRIX

\begin{tabular}{lll}
\hline \hline Position $\left(\mathrm{cm}^{-1}\right)$ & Transmission Intensity & Identification [13] \\
\hline 3466 & Vs, wide & O-H (stretching vibration) \\
2927 & $\mathrm{~S}$ & $\mathrm{C}-\mathrm{H}$ (stretching asymmetry of $\left.\mathrm{CH}_{2}\right)$ \\
2243 & Vw & C-N stretching \\
1882 & $\mathrm{~S}$ & $\mathrm{C}-\mathrm{N}$ stretching in aromatic \\
1620 & Vs & $\mathrm{C}=\mathrm{C}$ sceletal stretching \\
1595 & Vs & $\mathrm{C}=\mathrm{C}$ ring stretching \\
1448 & $\mathrm{~S}$ & $\mathrm{C}=\mathrm{C}$ ring stretching \\
1325 & $\mathrm{~S}$ & $\mathrm{C}-\mathrm{H}$ bending \\
1155 & $\mathrm{~S}$ & $\mathrm{C}-\mathrm{N}$ stretching in aromatic \\
840 & $\mathrm{~S}$ & $\mathrm{C}-\mathrm{H}$ (out of plane bending) \\
744 & $\mathrm{Vs}$ & $\mathrm{C}-\mathrm{H}$ (out of plane bending) \\
719 & Vs & $\mathrm{CH}$ (rocking vibration) \\
619 & $\mathrm{e}$ & $\mathrm{OH}$ (wagging) \\
\hline \hline
\end{tabular}

Note: Vs: very strong, S: strong, W: weak, Vw: very weak 
TABLE 3 .

IDENTIFICATION OF THE FTIR ABSORPTION PEAKS OF SUDAN III/PVK MOLECULE IN KBR MATRIX

\begin{tabular}{|c|c|c|}
\hline Position $\left(\mathrm{cm}^{-1}\right)$ & Transmission Intensity & Identification $[6,13,17]$ \\
\hline 3426 & S, wide & $\mathrm{O}-\mathrm{H}$ stretching of bounded intermolecular \\
\hline 2924 & $\mathrm{Vw}$ & $\mathrm{C}-\mathrm{H}$ asymmetric stretching \\
\hline 2854 & $\mathrm{Vw}$ & $\mathrm{C}-\mathrm{H}$ symmetric stretching \\
\hline 2962 & $\mathrm{Vw}$ & $\mathrm{C}-\mathrm{H}$ asymmetric stretcting \\
\hline 2873 & $\mathrm{Vw}$ & C-H symmetric stretching \\
\hline 1621 & $\mathrm{~S}$ & $\mathrm{C}=\mathrm{C}$ (ring stretching) \\
\hline 1595 & $\mathrm{~S}$ & $\mathrm{C}=\mathrm{C}$ (ring stretching) \\
\hline 1480 & $\mathrm{~S}$ & $\mathrm{C}=\mathrm{C}$ (ring stretching) \\
\hline 1497 & $\mathrm{~S}$ & $\mathrm{C}=\mathrm{C}$ (ring stretching) \\
\hline 1443 & Vw & $\mathrm{N}=\mathrm{N}$ stretching \\
\hline 1301 & $\mathrm{Vw}$ & $\mathrm{O}-\mathrm{H}$ bending vibration \\
\hline 1256 & VS & $\mathrm{C}-\mathrm{O}$ stretching vibration \\
\hline 1229 & $\mathrm{~S}$ & $\mathrm{OH}$ deformation \\
\hline 1207 & $\mathrm{~W}$ & $\mathrm{C}-\mathrm{O}$ stretching vibration \\
\hline 1174 & Vw & C-N stretching in phenyl \\
\hline 1131 & $\mathrm{~W}$ & $\mathrm{C}-\mathrm{O}$ stretching of $\mathrm{C}-\mathrm{OH}$ group \\
\hline 863 & $\mathrm{~S}$ & C-H out-of-plane bending \\
\hline 836 & $\mathrm{~S}$ & C-H out-of-plane bending \\
\hline $683 \mathrm{~S}$ & $\mathrm{~S}$ & C-H out-of-plane bending \\
\hline 617 & W & $\mathrm{OH}$ wagging \\
\hline
\end{tabular}

Note: Vs: very strong, S: strong, W: weak, Vw: very weak 